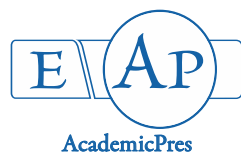

\title{
Characterization of Thirty Cultivars of Mangifera indica L. (Anacardiaceae) by Their Foliar Anatomical Traits
}

\author{
Bhavna Girish SHARMA ${ }^{1}$, Susy ALBERT ${ }^{1 *}$, Haresh Kumar DHADUK ${ }^{2}$ \\ ${ }^{1}$ The Maharaja Sayajirao University of Baroda, Department of Botany, Faculty of Science, Vadodara 390 002, Gujarat, \\ India; drsusyalbert@rediffmail.com ("*orresponding author); bs1384@gmail.com \\ ${ }^{2}$ Anand Agricultural University, Department of Agriculture Botany, B.A. College of Agriculture, Anand 3881 10, Gujarat, \\ India; hareshkumar01@rediffmail.com
}

\begin{abstract}
Leaves of thirty cultivars of Mangifera indica L. were investigated to compare their anatomical variations and identify the characteristic features which are potential markers for the identification of the cultivars. Variations were noted in the thickness of cuticle, length of epidermal cells in the abaxial and adaxial surfaces, length of palisade and spongy tissue. The length of epidermal cell varied from $10 \mu \mathrm{m}$ in 'Goto' to $25 \mu \mathrm{m}$ in 'Desi' cultivars on adaxial side, while on the abaxial side it varied from $15.5 \mu \mathrm{m}$ in 'Alphonso' to $6.9 \mu \mathrm{m}$ in 'Sopari'. The palisade tissue length was maximum in 'Jahangir' $(111.36 \mu \mathrm{m})$, while it was lowest in 'Fazli' $(24.13 \mu \mathrm{m})$. Spongy tissue length was the highest in 'Jamadar' (199.92 $\mu \mathrm{m})$ and lowest in 'Fazli' $(90.55 \mu \mathrm{m})$. Two layers of palisade tissue were seen in 'Sindoria', 'Jhumakhiya 2', 'Aambadi', 'Neelam', 'Rajapuri', 'Fazli', 'Jahangir', 'Kaju', and 'Aamir pasand', while three layers were seen in 'Alphonso', 'Jamadar', 'Ladvo', 'Sopari' and 'Dudhpendo'. Such parameters can be used for distinctly differentiating varieties among them and thus have an exact identification when morphological features are indistinguishable.
\end{abstract}

Keywords: cultivars; leaves; Mangifera; palisade; spongy; variation

\section{Introduction}

Mango, the king of fruits, has been acknowledged as an excellent fruit relished by everybody. It has been in cultivation in India since pre-historic times. Fruits are put to many uses right from the first stage of development, up to maturity and ripening stage. The mango is indigenous to North-East India and North Burma, in the foothills of the Himalayas and is said to have originated in the Indo-Burma region (De Candolle, 1904; Popenoe, 1920; Mukherjee, 1951). India probably has more commercial plantings than the rest of the world (Ochse et al., 1961). The leading mango-growing states in India are Uttar Pradesh, Andhra Pradesh, Bihar, Orrisa and West Bengal. All the cultivated Indian mangoes belong to the single species Mangifera indica $\mathrm{L}$., which is the most important member of the family Anacardiaceae. A few other edible species of Mangifera in the Malaysian region are M. odorata, $M$. foetida and $M$. caesia, which are also cultivated. However, fruits of no other species are as good in quality as those of $M$. indica.

Mango leaves are very important medicinally due to the presence of mangiferin, which is an expectorant for cough caused by bronchitis, and also helps in preventing asthma. Mango leaves are the main material sources for mango cough drops. It is effective in reducing fever, improving functions in tonifying the heart, diuresis, anti-melancholy, anti-inflammatory (Shah et al., 2010). In addition, mango has also been used as traditional medicine i.e. a bark infusion used in Samoa for mouth infections in children, whereas mango leaves used as a remedy for treatment of relapse sickness in Tonga (Odyek et al., 2007) in India (Scartezzini et al., 2000), The total number of distinct mango varieties cultivated in India has been variously estimated at 500 tol, 000 , out of which around 210 varieties are considered important.

Precise identification of the plant based on the external morphology is possible when a complete plant specimen is available. Anatomical characters can also facilitate the identification when morphological features are indistinguishable (David et al., 2008; Sultal et al., 2010). Khosravi and Poormahdi (2008) studied Polygonum population of Southwesst Iran which suggests histology and leaf anatomy could be considered significant characteristic. Ali et al. (2013) reported anatomical traits of leaves and stems to characterize some fig cultivars.

Although the importance of foliar epidermal anatomy for classification has been studied by many researchers (Dixon 2002; Sonibare et al., 2006; Khan et al., 2011; Mavi et al., 2011; Szymura and Wolski, 2011; Ergen Akein et al., 
548

2013; Fatihah et al., 2014), cultivars of M.indica have not yet been studied. Thus, the present work aims to investigate the anatomical variations between thirty mango cultivars and to utilize them for their indentification.

\section{Materials and Methods}

\section{Plantmaterial}

Five plants of each variety were used for the anatomical study. The samples containing leaf tissues were fixed in formalin-acetic acid-alcohol (70\%) 5:5:90 (v/v)) solution for 48 hours (Metcalfe, 1960). Leaves were cut into pieces, so as the midrib along with lamina regions from the middle part could be fixed. Fixed samples were dehydrated in a graded series $(20,35,55,75,95$ and $100 \%)$ of TBA (tertiary-butyl-alcohol) and embedded in paraffin wax (Johansen, 1940). Single staining with toluidine blue and double staining with safranin and fast green were done for the cross section. Serial sections of the leaf lamina of each variety were observed and micro-photographed to visualize the cuticle, resin canals, arrangement of vascular strands and other anatomical features.

\section{Results}

\section{Lamina}

Transection of the lamina had upper epidermis single layered made of barrel shaped cells. The epidermal cells were covered by a thick cuticle. The shape of epidermal cell and amount of cuticle deposition varied in the different varieties (Table 1). Quantitative features included length of epidermal cell on abaxial and adaxial side (Fig. 1A), length of pallisade and spongy tissue and number of epithelial layer surrounding resin canals (Table 1). Upper epidermis was homogenous. Upper and lower epidermis was covered by cuticle. Trichome and stomata were seen along with the lower epidermal region. The length of epidermal cell varied from $10 \mu \mathrm{m}$ in 'Goto' to $25 \mu \mathrm{m}$ in 'Desi', on adaxial side, while on the abaxial side it varied from $15.5 \mu \mathrm{m}$ in 'Alphonso' to $6.9 \mu \mathrm{m}$ in 'Sopari'.

\section{Midrib}

In the midrib region, next to epidermis, a layer of stone cells was observed. The layer was either continuous or interrupted by parenchyma cells. This region also showed presence of crystals, mainly consisting of two typessphaeraphides and rhomboidal. All the varieties invariably showed presence of rhomboidal crystal except in 'Desi' variety, which showed absence of rhomboidal, but presence of sphaeraphides. Some of the varieties showed presence of both (Table 1).

This was followed by parenchymatous cells in the cortex. The pallisade tissue length was maximum in

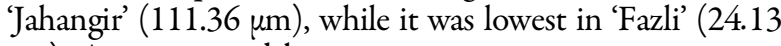
$\mu \mathrm{m})$. Area occupied by spongy tissue in a transverse view between the upper and lower epidermis varied within the different varieties. It was maximum in 'Jamadar' (199.92 $\mu \mathrm{m})$ and least in 'Fazli' $(90.55 \mu \mathrm{m})$. Ratio of pallisade to spongy was always found lower in all the varieties. The pallisade tissue length was highest in 'Jahangir' $(111.36 \mu \mathrm{m})$ while it was lowest in 'Fazli' $(24.13 \mu \mathrm{m})$. Spongy tissue length was highest in 'Jamadar' $(199.92 \mu \mathrm{m})$ and lowest in 'Fazli' $(90.55 \mu \mathrm{m})$. Number of the pallisade layer varied; it may be one, two or three. One layer of pallisade tissue was commonly seen in most of the varieties: 'Cowasji', 'Batli', 'Pairi', 'Jhumakhiya 1', 'Goto', 'Mulgoa', 'Rucchado', 'Ladvo', 'Khodi', 'Kesar', 'Langdo', 'Asadiyo', 'Badshahpasand', 'Desi', 'Totapuri', 'Jhamrukhiyo' and 'Gajariyo' (Fig. 1a,b,c,e,f, 2b,c,d,e,f, 3c,e, 4a,b, 5b,c,f). Two layers were seen in 'Sindoria', 'Jhumakhiya 2', 'Aambadi', 'Neelam', 'Rajapuri', 'Fazli', 'Jahangir', 'Kaju' and 'Aamir pasand' (Fig. 1d, 3a,d, 4c,e,f, 5d,e), while three layers were seen in 'Alphonso', 'Jamadar', 'Ladvo', 'Sopari' and 'Dudhpendo' distinctly differentiating them from the other varieties (Fig. 2a, 3b,f, 4d, 5a). Length of the pallisade cells in 2 and 3 layered was different (Fig. 3f, arrow).

Vasculature comprised of 8-10 vascular bundles separated by parenchyma cells. A wide phloem region was found on the upper side of the vascular bundles. Resin canals of different size were found embedded in this region. The resin canals were surrounded by one or two layer of epithelial cells (Table 1). Almost all the varieties had the resin canal surrounded by a single or two layer of epithelial layers varied from 3-4. The shape of the resin canals was round, oval or oblong. The xylem was formed of 3-5 rows of xylem vessels. The central pith region was made up of parenchyma cells. In the lamina region, next layer following epidermis was pallisade tissue. Followed by pallisade tissue, were 8-12 layers of spongy tissue, with differences in the compactness of arrangement. In varieties 'Cowasji', 'Jhumakhiya 1', 'Sindoria', 'Pairi', 'Rucchado', 'Ladvo', 'Khodi', 'Langdo', 'Neelum', 'Badshahpasand', 'Desi', 'Jhamrukhiyo', 'Gajariyo', spongy tissue was compactly arranged (Fig. 1a,c,d,e, 2c,d,e, 3c,f, 4a,b, 5c,f), while in 'Batli', 'Goto,' 'Jamadar', 'Mulgoa', 'Kesar', 'Jhumakhiya', 'Sopari', 'Aambadi', 'Asadiyo', 'Dudhpendo', 'Alphonso, 'Rajapuri', 'Fazli', 'Jahangir', 'Totapuri', 'Kaju', 'Aamirpasand', the spongy tissue was loosely arranged, with more intercellular spaces (Fig. 1b,f, 2a,b,f, 3a,b,d,e, 4c,d, e,f, 5a,b,d,e).

\section{Discussion}

The results obtained from the present study showed that the anatomical characters can be useful in variety identification and to evaluate their importance in taxonomy. Anatomical characters are found helpful in determining the relationship between different genera, families, orders and other taxonomic categories. Howard (1962), Schofield (1968), Dickson (1969, 1980), Datta and Dasgupta (1979) have indicated the importance of nodal and petiolar anatomy in taxonomic treatments. Heneidak et al. (2007) examined 15 tree species of the Fabaceae family (Papilionoideae) and showed the importance of the shape of the petioles, the features of the epidermal cells, fibres, crystal types, secretion elements, hairs and the anatomy of the vascular bundles. Martinez et al. (2009) reported that petiole anatomy contains taxonomic information that can be used in systematic studies in tribe Hameliaceae and other Rubiaceae members.

Essiest (2010) has divided the 3 genus on shapes and arrangement of vascular bundle in the petioles. 


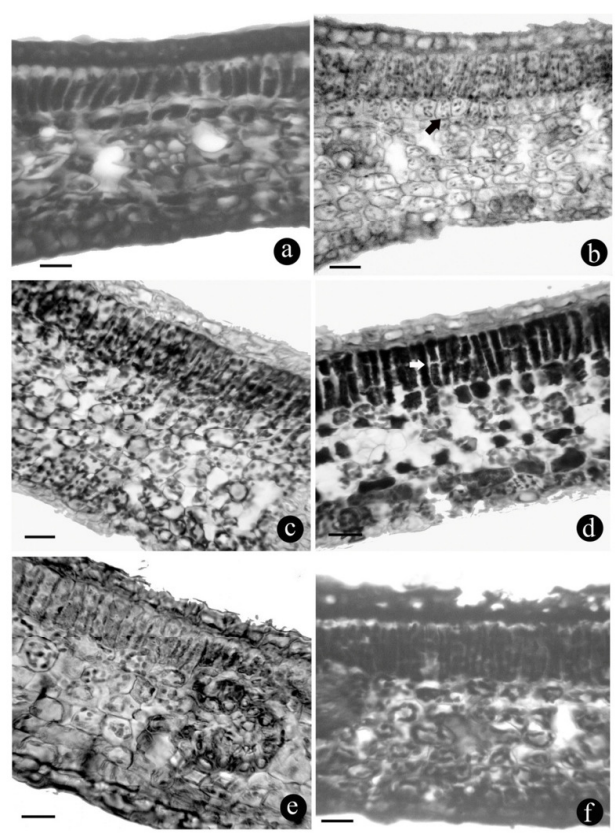

Fig. 1. Anatomical features of the leaf lamina in $M$. indica, magnification bar, a to $\mathrm{f}-10 \mathrm{~mm}$

a. 'Cowasji'- single layered palisade, spongy layer cells compactly arranged; b. 'Batli'- single layered pallisade, a continuous layer of spongy compact cells below pallisade (arrow); c. 'Jhumakhiya 1'- single layered pallisade, spongy layer compactly arranged; d. 'Sindoria'- two layer pallisade (arrow), spongy layer compact; e. 'Pairi'- single layered pallisade, spongy layer compact, rhomboidal crystal near vascular bundle; $f$. 'Goto'- single pallisade, spongy layer cells loosely arranged.

Table 1. Qualitative and quantitative internal features of lamina (mean \pm SD) (a-adaxial, b- abaxial, Rh- rhomboidal, Sp-sphaeraphides)

\begin{tabular}{|c|c|c|c|c|c|c|c|c|c|}
\hline \multirow[b]{2}{*}{ No. } & \multirow[b]{2}{*}{ Variety } & \multirow{2}{*}{$\begin{array}{c}\text { Thickness of } \\
\text { leaf }(\mu \mathrm{m})\end{array}$} & \multicolumn{2}{|c|}{ Length of epidermal cell $(\mu \mathrm{m})$} & \multicolumn{2}{|c|}{ Length $(\mu \mathrm{m})$} & \multirow[b]{2}{*}{ Shape of resin canal } & \multirow{2}{*}{$\begin{array}{c}\text { No. } \\
\text { of epithelial } \\
\text { layer }\end{array}$} & \multirow[b]{2}{*}{ Type of crysta } \\
\hline & & & a & $\mathrm{b}$ & $\begin{array}{c}\text { Pallisade } \\
\text { tissue }\end{array}$ & Spongy tissue & & & \\
\hline 1 & 'Cowasji’ & 181.14 & $14 \pm 1.2$ & $11.5 \pm 1.2$ & $38.55 \pm 6.9$ & $117.09 \pm 13.1$ & oval and elongated & 2 & $\mathrm{Rh}$ \\
\hline 2 & 'Batli' & 201.7 & $18.18 \pm 4.2$ & $14.54 \pm 5.4$ & $61.20 \pm 5.4$ & $107.86 \pm 8.7$ & oblong & $1-2$ & $\mathrm{Rh}$ \\
\hline 3 & 'Jhumakhiya 1' & 236.01 & $13.5 \pm 2.9$ & $10.25 \pm 0.7$ & $75.68 \pm 6.9$ & $137.08 \pm 20.4$ & round and oval & 2 & $\mathrm{Rh}$ \\
\hline 4 & 'Sindoria' & 293.13 & $21.96 \pm 6.7$ & $12.87 \pm 1.5$ & $78.78 \pm 5.5$ & $179.52 \pm 13.8$ & round, oblong & 1 & $\mathrm{Rh}, \mathrm{Sp}$ \\
\hline 5 & 'Pairi' & 180.2 & $12.8 \pm 1.5$ & $10.60 \pm 1.7$ & $42.42 \pm 11$ & $114.38 \pm 5.1$ & round & 1 & $\mathrm{Rh}$ \\
\hline 6 & ‘Goto’ & 206.21 & $10 \pm 0$ & $12 \pm 1.05$ & $57.12 \pm 0$ & $127.09 \pm 28.1$ & round & $3-4$ & $\mathrm{Rh}$ \\
\hline 7 & 'Jamadar' & 317.228 & $16.75 \pm 2$ & $13.5 \pm 2.9$ & $87.108 \pm 12$ & $199.92 \pm 13.4$ & round & $1-2$ & $\mathrm{Rh}$ \\
\hline 8 & 'Mulgoa' & 222.69 & $21.96 \pm 2.9$ & $10.60 \pm 1.7$ & $44.69 \pm 308$ & $145.44 \pm 6.5$ & round & $1-1$ & $\mathrm{Rh}$ \\
\hline 9 & 'Rucchado' & 231.2 & $12 \pm 2.5$ & $10.75 \pm 1.2$ & $69.97 \pm 8.1$ & $128.2 \pm 26$ & round & 1 & $\mathrm{Rh}$ \\
\hline 10 & 'Ladvo’' & 262.31 & $14.7 \pm 2.4$ & $10.5 \pm 1.0$ & $84.25 \pm 18.3$ & $145.6 \pm 9$ & round & 2 & $\mathrm{Rh}$ \\
\hline 11 & 'Khodi' & 225.23 & $15.75 \pm 2.3$ & $10.5 \pm 1.0$ & $58.54 \pm 10.5$ & $134.23 \pm 24.4$ & round and oval & 2 & $\mathrm{Rh}$ \\
\hline 12 & 'Kesar' & 189.82 & $15.75 \pm 1.3$ & $10.30 \pm 1.6$ & $63.63 \pm 3.0$ & $93.93 \pm 8$ & oblong & 1 & $\mathrm{Rh}$ \\
\hline 13 & 'Jhumakhiya 2' & 195.86 & $15.8 \pm 2.5$ & $12.3 \pm 0.8$ & $61 \pm 5.2$ & $102.6 \pm 18.6$ & round and oval & 1 & $\mathrm{Rh}, \mathrm{Sp}$ \\
\hline 14 & 'Sopari' & 276.44 & $20 \pm 1.6$ & $9.75 \pm 1.4$ & $79.96 \pm 12$ & $164.22 \pm 44.7$ & round and oval & 2 & $\mathrm{Rh}$ \\
\hline 15 & 'Langdo' & 277.36 & $21 \pm 1.5$ & $12.8 \pm 1.2$ & $75.1 \pm 4.8$ & $170 \pm 20.3$ & round and oval & 2 & $\mathrm{Rh}, \mathrm{Sp}$ \\
\hline 16 & 'Aambadi' & 211.78 & $14.39 \pm 2.9$ & $9.84 \pm 1.5$ & $60.6 \pm 2.4$ & $118.92 \pm 2.9$ & round, oblong & 1 & $\mathrm{Rh}$ \\
\hline 17 & 'Asadiyo' & 276.17 & $24.99 \pm 5.1$ & $12.87 \pm 1.5$ & $62.87 \pm 2.9$ & $181.04 \pm 5.1$ & oblong & 1 & $\mathrm{Rh}, \mathrm{Sp}$ \\
\hline 18 & 'Neelam' & 162.54 & $15.90 \pm 1.5$ & $9.84 \pm 1.5$ & $29.54 \pm 3.8$ & $100.74 \pm 4.5$ & round, oblong & $1-2$ & $\mathrm{Rh}$ \\
\hline 19 & 'Bsdshahpasand' & 288.59 & $16.36 \pm 1.6$ & $13.93 \pm 1.6$ & $71.50 \pm 5$ & $184.83 \pm 16.8$ & round & $1-2$ & $\mathrm{Rh}$ \\
\hline 20 & 'Desi' & 264.8 & $25.75 \pm 1.7$ & $12.87 \pm 1.5$ & $55.29 \pm 7.1$ & $177.25 \pm 9.4$ & oblong & $1-2$ & Sp \\
\hline 21 & 'Dudhpendo' & 196.48 & $15.75 \pm 1.6$ & $13.5 \pm 3.3$ & $49.98 \pm 7.5$ & $114.24 \pm 15.0$ & round & $2-3$ & $\mathrm{Rh}$ \\
\hline 22 & 'Alphonso' & 271.02 & $22.42 \pm 5.9$ & $15.15 \pm 2.1$ & $72.72 \pm 4.2$ & $166.04 \pm 9.1$ & round, oblong & $2-3$ & $\mathrm{Rh}, \mathrm{Sp}$ \\
\hline 23 & 'Rajapuri' & 232.99 & $24.24 \pm 2.4$ & $9.84 \pm 1.5$ & $61.35 \pm 1.5$ & $139.38 \pm 25.3$ & oblong & 1 & $\mathrm{Rh}$ \\
\hline 24 & 'Fazli' & 146.948 & $7.5 \pm 0.6$ & $6.9 \pm 1.1$ & $24.13 \pm 1.27$ & $90.558 \pm 5.2$ & round and oval & 2 & $\mathrm{Rh}, \mathrm{Sp}$ \\
\hline 25 & 'Jahangir' & 300.41 & $25 \pm 2.9$ & $21.97 \pm 1.5$ & $111.35 \pm 6.7$ & $156.80 \pm 5.1$ & round, oblong & 1 & $\mathrm{Rh}$ \\
\hline 26 & 'Totapuri' & 254.2 & $15.90 \pm 1.5$ & $10.60 \pm 1.7$ & $64.38 \pm 14.7$ & $157.56 \pm 6.5$ & oblong & $1-2$ & $\mathrm{Rh}$ \\
\hline 27 & 'Jhamrukhiyo' & 243.2 & $20.5 \pm 1.4$ & $14.2 \pm 1.5$ & $58.63 \pm 10$ & $152.31 \pm 3.2$ & round & 2 & $\mathrm{Rh}, \mathrm{Sp}$ \\
\hline 28 & 'Kaju' & 220.72 & $18.78 \pm 3.3$ & $13.93 \pm 1.6$ & $54.54 \pm 5.6$ & $133.92 \pm 9.6$ & oblong & $2-3$ & $\mathrm{Rh}, \mathrm{Sp}$ \\
\hline 29 & 'Aamir pasand' & 133 & $21.96 \pm 2.9$ & $12.87 \pm 1.5$ & $100.74 \pm 8.3$ & $149.98 \pm 3$ & round & $1-2$ & $\mathrm{Rh}$ \\
\hline 30 & 'Gajariyo’ & 87.55 & $18.93 \pm 3.8$ & $14.39 \pm 3.8$ & $55.29 \pm 5.1$ & $149.98 \pm 3$ & round & $1-2$ & $\mathrm{Rh}$ \\
\hline
\end{tabular}



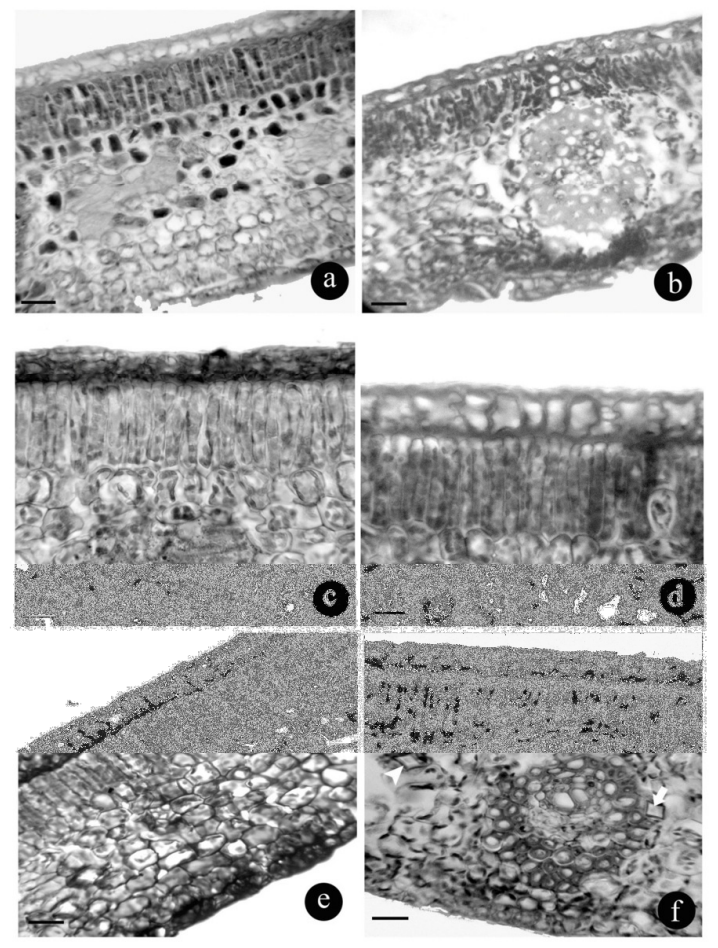

Fig. 2. Anatomical features of the leaf lamina in $M$. indica, magnification bar, a to $\mathrm{f}-10 \mathrm{~mm}$

a. 'Jamadar'- 3' layers of pallisade with cells of different size, spongy layer cells compactly arranged; b. 'Mulgoa'- single layered pallisade, spongy layer loosely arranged; c. 'Rucchado'- single layered pallisade, spongy layer compactly arranged; d. 'Ladvo'- single layered pallisade, spongy layer compactly arranged; e. 'Khodi'single layered pallisade, spongy layer compactly arranged; $f$. 'Kesar'- single pallisade, spongy layer loosely arranged, crystal at the periphery of vascular bundle (arrow) and in spondy layer cells (arrowhead)
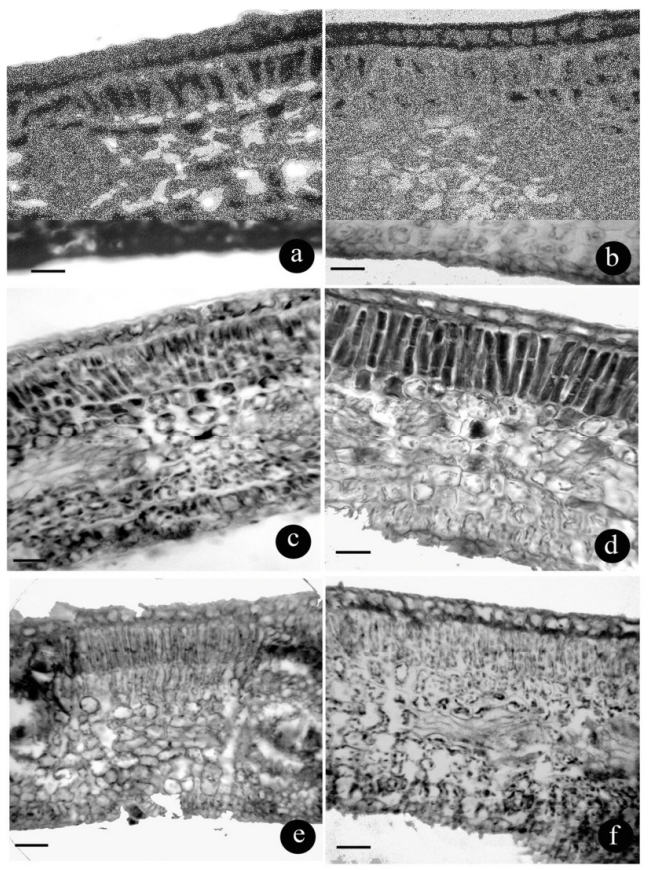

Fig. 4. Anatomical features of the leaf lamina in $M$. indica varieties, magnification bar, a to $\mathrm{f}-10 \mathrm{~mm}$

a. 'Badshahpasand'- single layered pallisade, spongy layer cells compactly arranged b. 'Desi'- single layered pallisade, spongy layer cells compactly arranged;

c. 'Dudhpendo'- 2 pallisade layers, spongy layer cells loosely arranged; d. 'Alphonso' - 3 pallisade layers, spongy layer cells compactly arranged; e. 'Rajapuri'2 pallisade layer, spongy layer cells loosely arranged; f. 'Fazli'- 2 pallisade layer spongy layer cells loosely arranged
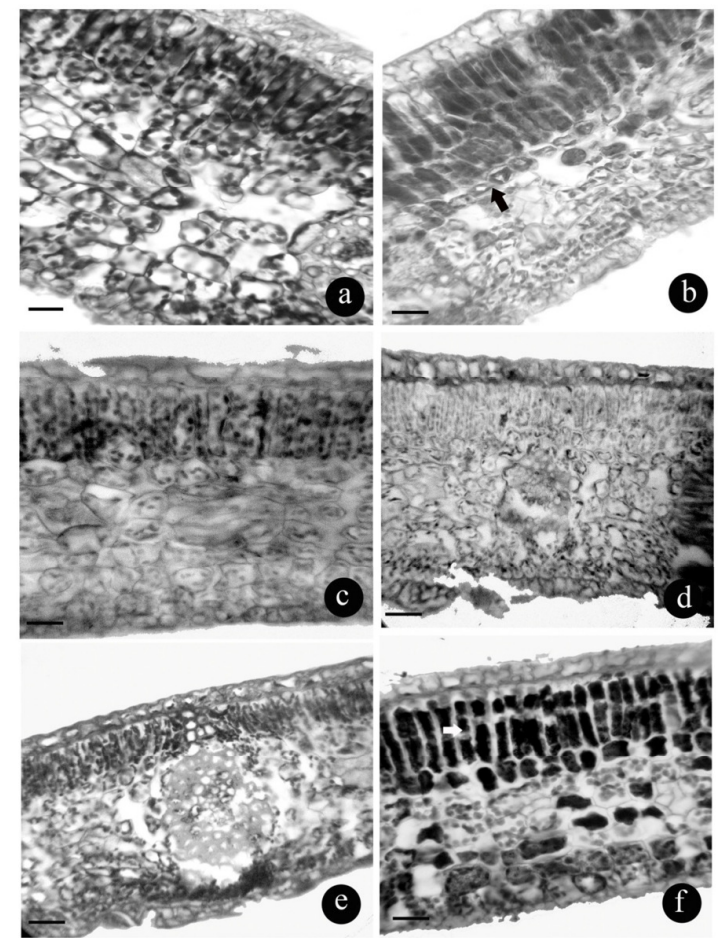

Fig. 3. Anatomical features of the leaf lamina in $M$. indica, magnification bar, a to $\mathrm{f}-10 \mathrm{~mm}$

a. 'Jhumakhiya 2'- 2 layer pallisade, spongy layer cells loosely arranged; b. 'Sopari' 3 compact layer of pallisade cells, continuous layer of spongy below pallisade (arrow); c. 'Langdo'- single pallisade, spongy compactly arranged; d. 'Aambadi'- 2 layer pallisade cells, spongy cells loosely arranged; e. 'Asadiyo' - single lavered pallisade, spongy loosely arranged; f. 'Neelam'- 3 layers loosely arranged pallisade of different length (arrow), spongy layer cells compactly arranged
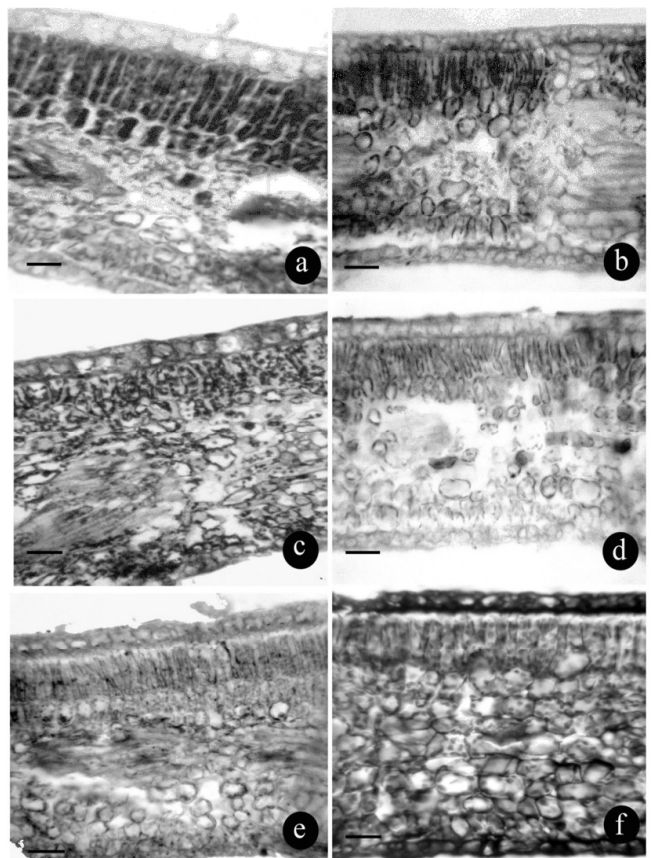

Fig. 5. Anatomical features of the leaf lamina in $M$. indica varieties, magnification bar: a to $\mathrm{f}-10 \mathrm{~mm}$

a. 'Jahangir'- 3 pallisade layer, spongy layer cells loosely arranged; b. 'Totapuri'single pallisade layer, spongy layer cells loosely arranged; c. 'Jhamrukhiyo'- single layered pallisade, spongy layer cells loosely arranged; $d$. 'Kaju'- 2 pallisade layer, spongy layer cells loosely arranged; e. 'Aamirpsand'- 2 pallisade layer, spongy layer cells loosely arranged; f. 'Gajariyo' - single layered pallisade, spongy layer cells compactly arranged 
Ogunrade and Saheed (2012) have described different species of Citrus according to the general outline of the median regions of petiole and they have also reported number of collenchyma cells layer to be diagonostic to some extent in the species. The shape of the vascular bundle was circular in 'Cowasji', 'Sindoria', 'Ladvo', 'Khodi', 'Langdo', 'Desi', 'Dudhpendo', while it was arc-shaped in 'Batli', 'Jhumakhiya 1', 'Pairi', 'Jamadar', 'Rucchado', 'Asadiyo', 'Neelam', 'Fazli', 'Jahangir' and 'Gajariyo', arc-shaped with 2 lobes in 'Mulgoa', 'Kesar', 'Jhumakhiya 2', 'Sopari', 'Aambadi', 'Alphonso', 'Rajapuri', 'Totapuri', 'Jhamrukhiyo' and 'Kaju'. Two very distinct shapes were seen in rest three varieties, broadly arc-shaped with 2 lobes in 'Goto', 'Badshahpasand' and deep arc-shaped with 2 lobes in 'Aamirpasand'.

Oznur et al. (2011) studied petiole anatomy of 7 taxa belonging to Lamiaceae describing the arrangement and number of vascular bundles in petiole, shape of vascular bundle, petiole shapes and presence of collenchyma and structure of epidermis. The arrangement of the vascular system in the petiole and the midvein can be useful in the diagnosis of some plant species. Maksymowych et al. (1983) examined petiole anatomy of 26 herbaceous and ligneous taxa and showed that the vascular bundles were positioned differently in each and every different type. In Rubiaceae, Kocsis et al. (2004) examined anatomy of the petioles, structure of the vascular bundles and the hair types and showed importance of these characters in taxonomic classification.

In recent years, anatomical characters have been used in taxonomy (Agbagwa and Ndukwu 2004; Kharazian 2007). The organization of the vascular system can be used in superior taxonomic levels in Rubiaceae (Martinez et al., 2009). The structure of petiole shows differences between genera and species. Thus, useful petiole and lamina anatomical characters are determined in designating taxonomical structures of some species but in the present study, it has been used to identify the variety of same genus and speices.

No significant correlation could be noticed in the cross sectional area and number of resin canals or diameter of the resin canal except in 'Sopari', with the maximum number of resin canals (13) and maximum diameter of the resin canals $(122.80 \mu \mathrm{m})$. In 'Goto', the number of resin canals was found to be the least, but the cross sectional area of the vessel element was found to be maximum $(79.3 \times 55.1 \mu \mathrm{m})$. The number of vessel elements in the main arc was found to be maximum in 'Sindoria' ( $362.3 \pm 12.3 \mu \mathrm{m})$, but the size (cross section) of the vessel elements were least in 'Jhumakhiya 2' (33.63 x $29.96 \mu \mathrm{m})$ indication that though the number of vessel elements was large, their size was small. The number of resin canals was less (13), but the diameter of it was larger $(122.80 \mu \mathrm{m})$ compared to that found in 'Jhumakhiya 2' which had more number of resin canals (16) of smaller diameter $(88.50 \mu \mathrm{m})$.

Epidermal cell was papillate in 'Rajapuri', 'Jhumakhiya 2' while they were much elongated in varieties 'Jahangir' and 'Jamadar', while were barrel shaped and radially elongated in all other varieties. Mavi et al. (2010) differentiated 2 species of Hordeum, mainly on the indumentation and epidermal cell wall properties. The cuticle penetration was important as it was used as one of the characters for differentiating the varieties. Varieties 'Batli', 'Jhumakhiya 1', 'Pairi', 'Jamadar', 'Sopari', 'Langdo', 'Aambadi', 'Fazli', 'Kaju', 'Kesar' and 'Jahangir' had cuticle adhering to the epidermal cell, 'Cowasji', 'Rucchado', 'Badshahpasand', 'Desi', 'Dudhpendo', 'Alphonso', 'Rajapuri', 'Gajariyo', 'Asadiyo', 'Neelam' and 'Jhamrukhiyo' had cuticle penetrating halfway, while 'Sindoria', 'Goto', 'Ladvo', 'Khodi', 'Jhumakhiya 2', 'Mulgoa', 'Totapuri' and 'Aamirpasand' had cuticle penetrating all along the epidermal cell. Thickness of cuticle ranged from $5 \mu \mathrm{m}$ to $13 \mu \mathrm{m}$. According to Ashton (1992), differences in cuticle thickness between species appears related to both light and drought tolerance. So, it can be said that the varieties 'Batli', 'Pairi', 'Rucchado', 'Khodi', 'Kesar', 'Aamirpasand' and 'Gajariyo', which had thick cuticle are drought tolerant and varieties 'Cowasji', 'Jhumakhiya 1', 'Sindoria', 'Ladvo', 'Jhumakhiya 2', 'Sopari', 'Aambadi', 'Asadiyo', 'Badshahpasand', 'Dudhpedno' and 'Jhamrukhiyo', having thin cuticle are drought intolerant.

Number of resin canal indicates more amount of secretion. Variety 'Sopari' had more amount of resin canal as compared to other varieties, while the number was very less in 'Goto'. Presence of crystal is also considered as an important crieteria. Crystals like sphaeraphides and rhomboidal crystal were found in the hypodermal region. Varieties 'Cowasji', 'Jhumakhiya 1', 'Goto', 'Mulgoa', 'Ladvo', 'Khodi', 'Badshahpasand', 'Dudhpendo', 'Alphonso' and 'Gajariyo' had both the crystals types present, while all the other varieties had only rhomboidal crystal present in hypodermal region. Dinc et al. (2008) found sphaerocrystal in the upper epidermal cell of leaf of Teucrium species. Lamina region also witnessed the presence of crystals in the upper epidermis, pallisade tissue and vascular bundle. Calcium oxalate crystals have been reported for defining the sub-families, tribes and sub-tribes of Rubiaceae (Arruda et al., 2010). Crystal distribution has been reported helpful in delimiting taxa by Metcalfe and Chalk (1950). Metcalfe (1983) has reported the significance of sphaero-crystal as it has restricted occurrence.

Around 4 to 12 resin canals were seen and categorized into big / small size and position in the midrib region. Mostly all the studied varieties had 2 big resin canals placed on either sides of the midrib vasculature within the lamina except for varieties 'Sindoria', 'Badshahpasand', 'Sopari' and 'Gajariyo' which had 3 or 4 big resin canals. Small resin canal ranged from 2 to 7 in number, but varieties 'Sindoria, 'Desi' and 'Rucchado' had 9, 10 and13 small resin canals respectively. Variety 'Sopari' was distinct in having 1 small resin canal in the centre of the midrib. The resin ducts are not located in the vascular bundles, but are merely associated with them in a characteristic and constant manner. In the petiole of the studied varieties, each vascular bundle is accompanied by a resin duct in the cortical region and opposite to the phloem. Resin duct here probably has an ecological role of protection. The chemical nature of the resin provides chemical protection against small assailants which if penetrated into the interior will be effectively discouraged from attacking the conducting strands, the continuity of which is vital to the wellbeing of the plant. Similarly, presence of raphides and sphaeraphides perfoms an ecological function of providing mechanical protection against pathogens.

The amount of vessels was found maximum in varieties 
552

'Sindoria', 'Rajapuri' and 'Batli', while it was minimum in 'Fazli'. Ozdemir and Senel (1999, 2001) showed the importance of the amount of vascular bundles and their arrangement within the petiole in the Salvia species. Data obtained was used for proper and easy identification and clarification of the taxonomic relationship of these species.

Mavi et al. (2010) found that the leaf blades vary between the taxa in both qualitative and quantitative value. In the present study, lamina region variation was seen in the layer of pallisade tissue, where it was single in many varieties, double in 'Batli', 'Jhumakhiya 1', 'Sindoria', 'Goto', 'Jhumakhiya 2', 'Aambadi', 'Neelam', 'Alphonso', 'Rajapuri', 'Fazli', 'Jahangir', 'Kaju' and 'Aamirpasand', while 3 layers were seen in 'Jamadar', 'Ladvo', 'Sopari' and 'Dudhpendo'. Salimpur et al. (2009) reported 3 species of Geranium with single layer of pallisade, 2 species with two layer pallisade and some with 3 to 6 layers of pallisade.

The leaves of all the varieties were dorso-ventral with the upper epidermis underlain by one to three layered cylinders. Pallisade tissue was loose in texture having its radial walls separate form one another. This feature connected with the necessity for the presence of air spaces in immediate contact with the photosynthetic cells also indicates that each pallisade element has a tendency to become independent of its neighbouring cells, neither receiving raw food materials from the latter, nor supplying them with synthetic products. They carry out the interchange of materials with its two extremities. Frequently in some varieties (plate 4e, 5b), a small group of pallisade cells converge at their lower ends so as to form a little fan shaped group resting upon a single underlying cell, the upper end of which is delated indicating them to be collecting cells, which receive the photosynthetic products from all the members of a group of pallisade cells and transmit them more or less directly to the main channels of translocation.

Anatomical studies indicated variation occurring between varieties, which could be a useful tool in identifying them. Leaf anatomy showed variation in the thirty varieties studied. It varied mainly in the number and arrangement of palisade layers, location and number of resin ducts in the midrib and location and intensity of inclusion like sphaeraphides and crystals.

\section{Conclusions}

The present study revealed that the foliar anatomical traits are of great taxonomic importance in differentiating mango varieties. Epidermal cell length, number of palisade layer, vascular bundle and type of resin canal give clues for identification of the variety.

\section{References}

Agbagwa OI, Ndukwu BC (2004). The value of morphoanatomical features in the systematic of Cucurbita L. (Cucurbitaceae) species in Nigeria. African Journal of Biotechnology 3(10):541-546.

Ali ZA, Mustafa NS, Abdel-Raouf HS, El-Shazly SM, El-Berry IM (2013). Characterization of some fig cultivars by anatomical traits on both leaves and stems. World Applied Sciences Journal 24(8):1065-1071.

Cutler DF, Botha CEJ, Stevenson DW (2008).Plant anatomy: an applied approach. Malden, MA, USA, Blackwell Publishing.

Datta PC, Dasgupta A (1979). Comparison of vegetative anatomy of Piperales: III. Vascular supplies to leaves. Acta Botanica Indica 7(1):3946.

De Candolle A (1904). Origin of cultivated plants. Kegan Paul, Trench, Trulener and Co. Ltd, London, UK. Origin of cultivated plants. Kegan Paul, Trench, Trulener and Co.Ltd, London, UK.

Dickson WC (1969). Comparative morphological studies in Dilleniaceae: IV. Anatomy of the node and vascularization of the leaf. Journal of Arnold Arboretum of Harvard University 50(3):384 110.

Dickson WC (1980). Diverse nodal anatomy of the Cunoniacae. Americal Journal of Botany 67(6):975-981.

Dinc M, Duran A, Pinar M, Ozturk M (2008). Anatomy, palynology and nutlet Micromorphology of Turkish endemic Teucrium sandrasicum (Lamiaceae). Biologia 63(5): 637-641.

Essiest UA (2010). Petiole anatomy for systematic purposed in Eremomastax polysperma, Justicia insularis and Asystacia gangetica (Acanthaceae). World Journal of Applied Science and Technology 2(1):69-75.

Heneidak SA, Samai Shaheen M (2007). Characteristics of the proximal to distal regions of the petioles to identify tree species of PapilionoideaeFabaceae. Bangladesh Journal of Plant Taxonomy 14(2):101-115.

Howard RA (1962). The vascular structure of the petiole as a taxonomic character. In Proceedings of the $\mathrm{XV}^{\text {th }}$ International Horticultural Congress, Nice 1958 New York, Pergamon Press pp7-13.

Johansen DA (1940). Plant microtechnique. New York: McGraw-Hill Book Company, Inc.

Kharazian N (2007). The taxonomy and variation of leaf anatomical characters in the genus Aegilops L. (Poaceae) in Iran. Turkish Journal of Botany 31:1-19.

Khosravi AR, Poormahdi S (2008). Polygonum khajeh-jamall (Polygonaceae), a new species from Iran. In:Annales Botanici Fennici (45(6):477-480). Finnish Zoological and Botanical Publishing Board.

Kocsis MJ, Borhidi A (2004). Comparative leaf anatomy and morphology of some neotrophical Rondeletia (Rubiaceae) species. Plant Systematic and Evolution 248:205-218.

Maksymowych AB, Orkwiszewski AJ, Maksymowych R (1983). Vascular bundles in petioles of some herbaceous and woody dicotledons. American Journal of Botany 70(9):1289-1296.

Martínez-Cabrera D, Terrazas T, Ochoterena H (2009). Foliar and petiole anatomy of tribe Hamelieae and other Rubiaceae. Annals of the Missouri Botanical Garden 96(1):133-145.

Mavi DO, Dogan M, Cabi E (2010). Comparative leaf anatomy of the genus Hordeum L. (Poaceae). Turkish Journal of Botany 35(4):357368.

Metcalfe CR, Chalk L (1950). Anatomy of the Dicotyledons: leaves, stems and wood in relation to taxonomy- with notes on economic uses. led. Vol. 1. Clarendon Press, Oxford pp 1498.

Metcalfe CR, Chalk L (1983). Anatomy of the Dicotyledons II, Oxford University Press, London.

Mukehrjee SK (1951). Origin of mango. Indian Journal of Genetics and Plant Breeding 11:49-56.

Ochse JJ, Soule MJ, Dijkman MJ, Wehlburg C (1961). Tropical and 
subtropical agriculture. Soil Science 91(5):356.

Odyek O, Bbosa GS, Waako P (2007). Antibacterial activity of Mangifera indica L. African Journal of Ecology 45(1):13-16.

Ogunrade CS, Saheed SA (2012). Foliar epidermal characters and petiole anatomy of four species of Citrus L. (Rutaceae) from south-western Nigeria. Bangladesh Journal of Plant Taxonomy 19(1):25-31.

Ozdemir C, Senel G (1999). The morphological, anatomical and karyological properties of Salvia sclarea L. Turkish Journal of Botany 23(1):7-18.

Ozdemir C, Senel G (2001). The morphological, anatomical and karyological properties of Salvia forskablei L. (Lamiaceae) in Turkey. Recent researches in plant anatomy and morphology. Jodhpur: Scientific Publishers (India) Jodhpur: Scientific Publishers (India) pp 297-313.
Popenoe W (1920). Manual of tropical and subtropical fruits. The Macmillan Co, New Yorkpp 474.

Salimpur F, Mazooji A, Onsori S (2009). Stem and leaf anatomy of ten Geranium L. species in Iran. African Journal of Plant Science 3(11):238244.

Scartezzini P, Speroni E (2000). Review on some plants of Indian traditional medicine with antioxidant activity. Journal of Ethnopharmacology 71(1):23-43.

Schofield EK (1968). Petiole anatomy of the Guttiferae and related families. Mem. NewYork Botanical Garden 18(1):1-55.

Shah KA, Patel MB, Patel RJ, Parmar PK(2010). Mangifera indica (mango). Pharmacognosy Reviews 4(7): 42 .

Sultan HA, BI Abu Elreish, YSM Yagi (2010). Anatomical and phytochemical studies of the leaves and roots of Uginea grandiflora Bak. and Pancratium turtuosum Herbert. Ethnobotanical Leaflets 7:12. 